\title{
Removing Barriers and Creating Opportunities for Climate-Resilient Agriculture by Optimizing Federal Crop Insurance
}

\section{$\underline{\text { Laura K. van der Pol }}{ }^{1,2,3}$, Clara A. Tibbetts ${ }^{1,4}$, Danielle E. Lin} Hunter $1,2,5$

${ }^{1}$ Colorado State University, School of Global Environmental Sustainability Leadership Fellowship Program, Fort Collins, CO

${ }^{2}$ Colorado State University, Graduate Degree Program in Ecology, Fort Collins, CO

${ }^{3}$ Colorado State University, Soil \& Crop Sciences Department, Fort Collins, CO

${ }^{4}$ Colorado State University, Chemistry Department, Fort Collins, CO

${ }^{5}$ Colorado State University, Biology Department, Fort Collins, CO

https://doi.org/10.38126/ISPG180213

Corresponding author: laura.vanderpol@colostate.edu

Keywords: crop insurance; agriculture; climate change; diversification; nature-based solutions

Executive Summary: Climate change is devastating global agricultural and economic systems. Nature-based solutions that promote conservation agriculture can address these challenges while mitigating climate change. We propose a pilot crop insurance and research program in the U.S. Northern Plains to promote practices that enhance farm soil health, income, and resilience while mitigating climate change. Such a program could inform nationwide adoption of such practices. We specifically propose eliminating requirements for fallow to insure wheat, funding development of regionally-adapted leguminous crops, and incentivizing whole farm insurance over single-crop yield-focused offerings to promote economic growth and climateresilient practices. The policies extend across a spectrum of cost, legislative burden, political capital, and time-scales for implementation and impact, offering a balanced and gradual transition to conservation agriculture. Adopted jointly, these recommendations improve farm resilience to climate change by promoting soil health and crop diversification while reducing emissions.

\section{Climate change and agriculture}

i. Financial cost of climate change in agriculture

Increased temperatures and extreme weather events of the past decades are expected to worsen, with projected temperature increases of 1 to $3^{\circ} \mathrm{C}$ by 2050 (Ray et al. 2015; Hatfield and Takle 2014). While temperature increases might lengthen certain crops' growing seasons, the overall effect of climate change will increase crop failure and reduce yields (Lobell and Gourdji 2012; Wienhold et al. 2018).

Many farmers purchase crop insurance managed by the U.S. Department of Agriculture (USDA) as protection from devastating crop loss, and taxpayers cover $\sim 60 \%$ of premium costs for this Federal Crop Insurance Program (FCIP) (Bryant and O'Connor 2017). Under a $2^{\circ} \mathrm{C}$ warming scenario, economists estimate the tax-burden for payouts to increase by \$3.7 billion (Tack, Coble, and Barnett 2018). Cost increases are exacerbated by the increasing value of insured crops, which leads to greater liability to taxpayers (Bryant and O'Connor 2017). Efforts to optimize FCIP are, therefore, economically important. 


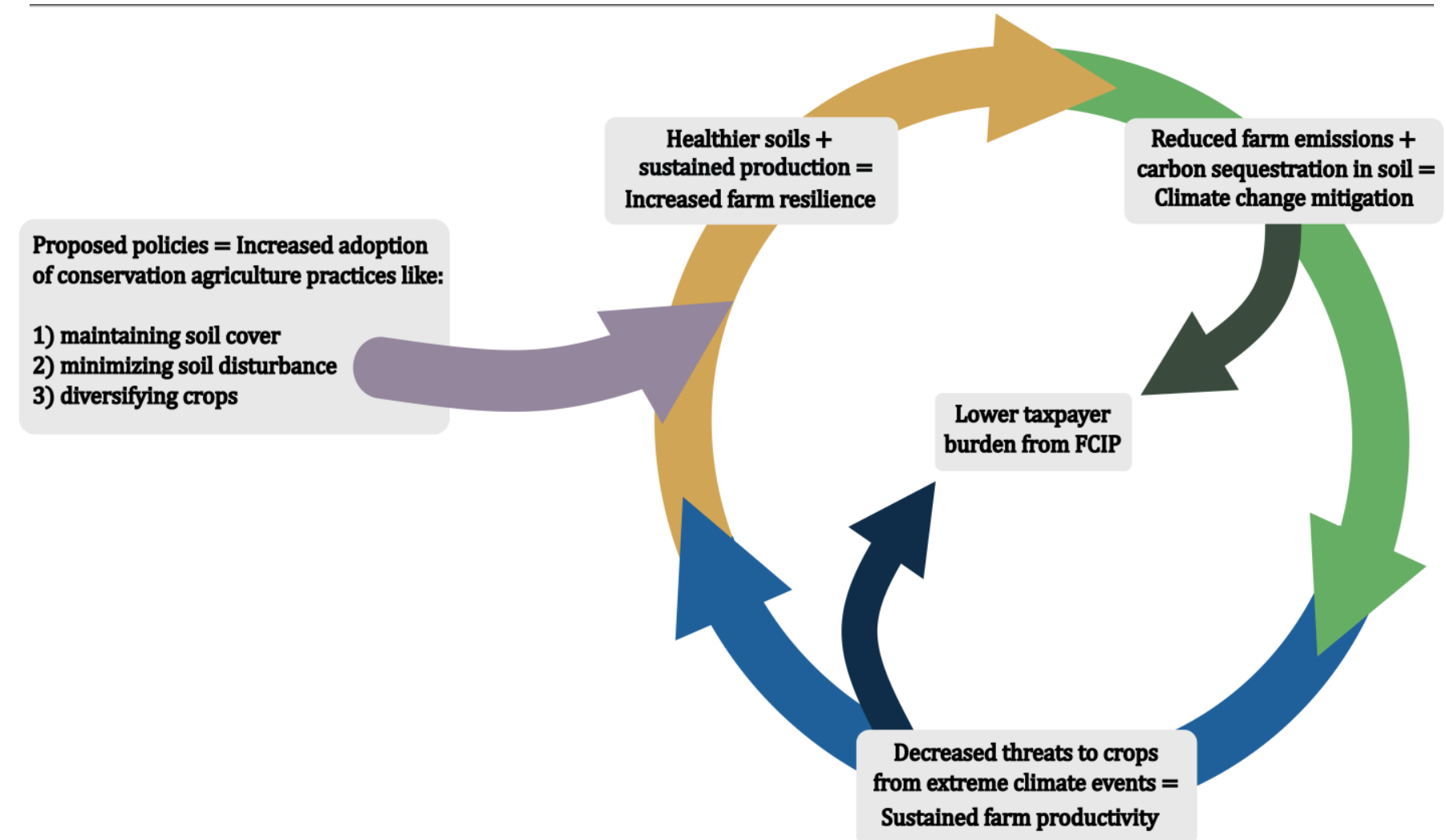

Figure 1: The proposed policy options would modify U.S. Department of Agriculture research funding and aspects of the Federal Crop Insurance Program (FCIP) to enhance conservation agriculture. Through a feedback loop, these changes would lead to food systems becoming more resilient to climate-induced extreme events, potentially lower costs of FCIP, and mitigate climate change through reduced greenhouse gas emissions and carbon sequestration.

ii. Synergy between conservation agriculture and climate change mitigation

Agricultural practices and climate change are linked (Fig. 1). Farming practices such as monocropping, fallow, and tillage have degraded soils, making them more dependent on energy-intensive management and susceptible to crop loss (Sanderman, Hengl, and Fiske 2017; Tilman et al. 2002). The extreme climatic events that characterize climate change also threaten continued ability to cultivate crops (Hunter et al. 2017). Thus, there are clear feedbacks between agricultural practices and climate change.

Conservation practices, on the other hand, can rebuild soil health. For example, diversifying crops, maintaining soil cover, and minimizing disturbance can restore soil structure, facilitate nutrient cycling, and promote carbon sequestration (Robertson et al. 2018; Knowler and Bradshaw 2007). Specifically, the formerly grassland soils of the Northern Great Plains offer potential climate change mitigation because poor management has led to the depletion of more than half the original soil carbon, consequently providing the opportunity to rebuild soil carbon through conservation practices (Lal 2018; Kern and Johnson 1993). Incremental increases to soil carbon are a significant, affordable, and agronomically beneficial means of greenhouse gas (GHG) reduction (Chenu et al. 2019). Enhancing soil carbon can also increase crop yields, farm resilience to extreme events, and lower FCIP payouts (Kane et al. 2021; Bowles et al. 2020; Oldfield, Bradford, and Wood 2019). Thus, conservation agriculture is an effective nature-based solution to climate change because practices that increase soil health simultaneously mitigate climate change (Bossio et al. 2020).

\section{Imperative for focusing on semi-arid region and legumes for diversification}

Our recommendations focus on the semi-arid Northern Great Plains due to compelling evidence of the benefits of conservation agriculture in this region and the historical practice of the USDA to implement reforms to FCIP after testing in a localized region (Hamilton 2020). This area frequently experiences drought and extreme temperatures, making it prone 
to FCIP payouts (U.S. Government Accountability Office 2015). As climate change is expected to expand semi-arid regions and intensify these events, farmers in other geographic regions will increasingly be faced with similar environmental challenges (IPCC 2019). Simultaneously, the funding and capacity of plant breeding programs in the U.S. have declined, forcing plant breeders to focus on maintaining infrastructure rather than diversifying crops (Coe et al. 2020). Few crop breeding programs exist for legumes, yet legumes offer great potential to offset fertilizer use while enhancing soil health and carbon sequestration (Rubiales et al. 2015; Cernay et al. 2015; Peoples et al. 2009; Jensen and Hauggaard-Nielsen 2003). We thus focus our recommendations on this region and specifically target legumes for regional crop development. If effective in reducing FCIP costs and improving agriculture resilience on a regional level, our recommendations could be scaled nationally.

\section{Strategies and policy options to promote conservation agriculture}

As climate change threatens agriculture and amplifies financial burdens on farmers and taxpayers, urgent modifications to FCIP and USDA research funding that promote nature-based solutions are imperative. We suggest this be implemented as a pilot program due to the precedent that the USDA uses pilots to trial reform measures (Hamilton 2020).

We recommend three specific changes:

1) Eliminate county-level fallow requirements

2) Fund research and market development for regionally-adapted legumes to provide suitable fallow alternatives

3) Phase out single-crop, yield-based coverage and incentivize whole farm revenue protection

If adopted, these policies would reduce GHG emissions, improve soil health and farm income, and confer greater resilience to climate change (Fig. 1).

\section{i. Eliminate county-level fallow requirements for wheat to promote soil health and crop diversification}

In the early $20^{\text {th }}$ century, agriculturalists advised farmers to stabilize winter wheat yields by implementing fourteen months of bare fallow to store water in the soil before planting (Peterson et al. 2020). Decades of research have shown, however, that the fallow does not store water efficiently
(Nielsen and Vigil 2010). Fallow periods also promote erosion, soil carbon and nutrient loss, and limit soil water-holding capacity. Thus, fallow periods can reduce farm resilience to extreme events (Rosenzweig and Schipanski 2019).

The rise of no-till farming, in which the crops are planted without plowing, has allowed many farmers to plant a productive crop annually without summer fallow periods. This practice thus protects soil from erosion, increases soil carbon, and leads to greater overall yield and income (Peterson et al. 2020; Rosenzweig, Fonte, and Schipanski 2018). The adoption of more frequent and diverse cropping practices, however, has been hindered by FCIP policy that requires fallow prior to sowing wheat to insure the crop (Rosenzweig, Carolan, and Schipanski 2019).

Farmers in Colorado and surrounding states already recognize the advantages of cultivating diverse crops and curtailing fallow. More than 0.5 million hectares reduced the frequency of summer fallow by incorporating more frequent short-season crops between 2008 and 2016, for example, by shifting to a wheat-corn-fallow rotation (Rosenzweig and Schipanski 2019). The reduction of fallow has resulted in an estimated $9 \%$ increase in grain production, an $\$ 80$ million increase in farm income, and a 3\% reduction of annual GHG emissions from the Colorado agricultural sector-equivalent to emissions from 70,000 passenger vehicles (Rosenzweig and Schipanski 2019). Broader elimination of fallow is limited by FCIP, whose coverage varies by county: $78 \%$ of eastern Colorado counties require fallow before planting wheat to be eligible for crop insurance. Removing the fallow requirement would promote more frequent and diverse crops with the potential to increase regional grain production by $25 \%$, raise farm income by $26 \%$, and almost completely offset GHG emissions caused by dryland (non-irrigated) grain (Rosenzweig and Schipanski 2019).

\section{Advantages}

- Removing the fallow requirement would provide greater farmer autonomy, allowing them to select the best strategies for their farm and climate. It would permit farmers to crop continuously-a practice that has been shown to benefit soil health, yield, and farm income-while concurrently mitigating climate change through 
reduced net GHG emissions and increased soil carbon sequestration (Jensen et al. 2012)

- Efforts to promote soil health can increase agricultural yield and therefore reduce taxpayer risk through FCIP

- Changes to existing policy requirements can be made at no cost of implementation

\section{Disadvantages}

- Fallow can enhance yield the year wheat is harvested, though it reduces yields averaged over a rotation cycle (Nielsen, Lyon, and Miceli-Garcia 2017), so trade-offs between long- and shortterm benefits must be considered

- Barriers beyond FCIP requirements influence grower adoption of conservation agricultural practices. Additional policy changes are also required to achieve resilient agricultural systems

ii. Fund research and market development for regionally-adapted legumes to provide suitable fallow alternatives and increase crop diversity

The variety of crops planted in the U.S. is decreasing (Crews, Carton, and Olsson 2018). From 1945 to 2007, the Corn Belt acreage devoted to corn and soybean increased from $29 \%$ to $80 \%$ (Claassen, Langpap, and $\mathrm{Wu} 2017$ ). FCIP incentivizes planting a small number of commodity crops in excess of domestic need, exacerbating crop homogenization, depressing commodity prices, and making food systems vulnerable (Beckie et al. 2019; Bryant and O’Connor 2017). Suitable alternatives are urgently needed. Moreover, removal of fallow requirements, per Recommendation 1, will further drive the need for suitable alternatives to fallow.

Historically, the emergence of a new crop is preceded by significant public investment in research, crop breeding, and market development (Zander et al. 2016; Cernay et al. 2015). For example, USDA-funded research led soybean yield to double since 1965, and USDA-developed corn varieties made it possible to plant in northern regions previously too risky to sow due to cold and dry conditions (Anderson et al. 2019; Plant Breeding Working Group 2015). This research led to increased yields and nutrition and furnished the seeds utilized by private corporations today. In addition, other countries have successfully increased farm diversification and economic opportunity by investing in crop breeding and marketing (Maaz et al. 2018). Canada invested CAN $\$ 18$ million in the 1970s to develop the edible oilseed canola, which resulted in CAN $\$ 1$ billion in benefits to growers and a return on investment to taxpayers of over CAN\$700 million (Brewin and Malla 2012). These investments have led to success, in part, because they developed crops for specific climate regions. Hence, we propose similarly scaled investments to research regionally-adapted pulse $^{1}$ crops for the U.S. Northern Plains.

Alternative crops could benefit local economies while conferring many ecological benefits from diversification (Petersen-Rockney et al. 2021). For this pilot program, legumes offer the greatest potential, as they have short growing seasons (minimizing water use), enhance nutrient cycling, boost subsequent crop yield, reduce reliance on fossil-fuel-based fertilizers, and provide a proteinrich food source (Stagnari et al. 2017; Zander et al. 2016; Crews and Peoples 2004). Additionally, many legumes could be bred for intercropping, which would allow for simultaneous forage ${ }^{2}$ and grain production and have the potential to enhance carbon sequestration (Wahbi et al. 2016; Li et al. 2001; Li et al. 2014; Drinkwater, Wagoner, and Sarrantonio 1998). Grain rotations that include legumes have been shown to use $12-34 \%$ less energy, and pulses use $35-60 \%$ less fossil energy compared to grain crops (Jensen et al. 2012). Despite these benefits, there is only one legume variety trial and no research levee in the region (Jacob, Carrasco, and Schwember 2016; Rubiales et al. 2015).

Currently, farmers considering legume agriculture are also limited by lack of infrastructure for storage and shipping. Public investment in infrastructure and marketing, however, can lead to increased crop diversity, as demonstrated by increased pea planting following the construction of a publicly funded granary in western Nebraska (Stepanovic et al. 2016). Therefore, we recommend that the USDA allocate funding to sustained research and market development for regionally-adapted legumes as an essential step towards resilient agriculture.

\footnotetext{
${ }^{1}$ Pulse crops are leguminous crops harvested for their dry seed and tend to have a short growing period. ${ }^{2}$ Forage crops are grown for the edible plant tissue (i.e., leaves and stems, not grain) as animal feed.
} 


\section{Advantages}

- Public investment in crop breeding and market development has potential for a high rate of return (Rubiales et al. 2015).

- Current lack of funding in regionally-adapted legumes means that moderate investments may provide substantial gains (Rubiales et al. 2015).

- Increased legume cropping would promote soil health and carbon sequestration.

- Diverse alternatives for a fallow period would increase the impact of the FCIP fallow requirement elimination (Recommendation 1 ).

\section{Disadvantages}

- Long-term investment in research, infrastructure, and market development requires sustained resources and political will.

- Mitigating rapid and catastrophic consequences of climate change requires action at a pace faster than that of research and market development.

iii. Phase out single-crop, yield-based coverage and incentivize whole farm insurance

Most FCIP products insure individual crops based on yield history rather than farm income (Hamilton 2020). The emphasis on yield and penalty ${ }^{3}$ for any management that may compromise yield in the shortterm, such as cover or continuous cropping, has led farmers to focus on a few high-value, high-yield crops that rely on high levels of inputs (e.g., fertilizers and herbicides) at the expense of long-term soil health and resiliency (Hamilton 2020). Additionally, the current structure of FCIP may discourage planning for extreme events, such as increased frequency and duration of drought and elevated temperatures. A study found insured corn was $67 \%$ more prone to extreme heat than uninsured corn (Annan and Schlenker 2015), suggesting that uninsured farms were more proactive in protecting against this common cause of crop loss, for example by planting at a crop density likely to provide a yield even under hot, dry conditions. Rather than insuring single crops based on yield, an alternative is to insure farm revenue, thus removing the emphasis on particular practices or crops while still protecting farms against devastating losses (Hamilton 2020).
The 2014 Farm Bill created such an insurance option called Whole Farm Revenue Protection (WFRP), though less than $2 \%$ of growers participate due to reluctance to change and unfamiliarity with the program (Mulik 2017). Incentivizing WFRP while phasing out subsidies for single-crop insurance could promote holistic planning and riskmanagement while reducing barriers to diversified rotations (Beckie et al. 2019). WFRP also offers an opportunity to develop a definition of a "good farming practice" that includes protection and regeneration of soil health, addresses GHG emissions reduction, and prioritizes or requires crop diversity, as is done in the European Union's Common Agriculture Policy (Meynard et al. 2013).

As the WFRP program has been in place with little adoption, we recommend that the USDA develop specific guidelines for how to transition between programs in collaboration with farmers and relevant member-based organizations. Genuine opportunity to inform policy and incorporate longterm planning into what constitutes a "good farming practice" could promote farmer buy-in for such a transition, improve the quality and efficacy of FCIP, and enhance adoption of conservation agriculture (Lovett 1999). Ultimately, shifting to WFRP while incentivizing conservation agriculture will reduce cost of insurance offerings by building farm resiliency (Beckie et al. 2019; Bryant and O'Connor 2017).

\section{Advantages}

- WFRP is an existing FCIP option that eliminates many of the institutional drivers towards monoculture and energy-intensive agriculture. Thus, no new programs or funding mechanisms are required to transition away from single-crop policies.

- Collaboration with growers about WFRP policies can encourage adoption of conservation agricultural practices.

- Increasing subsidies for WFRP while gradually reducing subsidies for single-crop insurance would provide a transition period for growers to adopt different agricultural practices while reducing taxpayer risk to rising costs of FCIP.

\footnotetext{
${ }^{3}$ Any practice that does not meet the Risk Management Agency's (RMA) description of a "good farming practice" could lose coverage. A good practice is one that "produce[s] the insured crop and allow[s] it to make normal progress toward maturity and produce at least the yield used to determine the production guarantee or amount of insurance" (RMA 2016, 33).
} 


\section{Disadvantages}

- This approach may be met with resistance, as insurance agents with established customers are reluctant to promote WFRP, given its reliance on tax records instead of yield history. Insurance companies currently require more documentation for WFRP than single-crop insurance, such as proof of markets and receipts for fertilizer and herbicide, to satisfy what insurance agents consider "good farming practices," though such receipts are not requested for other insurance policies. The additional paperwork and research for specialty crops creates an additional bureaucratic burden that impedes adoption by many commodity farmers that could be eliminated. This transition would require collaboration with growers and careful planning to be politically feasible.

\section{iv. Synergistic benefits of combined policies}

Alone, each recommended policy change is an improvement over the status quo but will not achieve the goal of creating climate-resilient farms. We propose three changes as key elements of a pilot program in keeping with USDA tradition (Hamilton 2020 ) so they can be ground-tested, modified, and scaled effectively. Together, these changes address bureaucratic obstacles, provide a range of short- and long-term solutions, and promote economic and agricultural sustainability (Fig. 1). The policies extend across a spectrum of cost, legislative burden, political capital, and time-scales for implementation and impact, offering a balanced and gradual transition to conservation agriculture. Adopted jointly, these

\section{References}

Anderson, Edwin J., Md Liakat Ali, William D. Beavis, Pengyin Chen, Tom Elmo Clemente, Brian W. Diers, George L. Graef, et al. 2019. "Soybean [Glycine max (L.) Merr.] Breeding: History, Improvement, Production and Future Opportunities." In Advances in Plant Breeding Strategies: Legumes, 7:431-516. Springer International Publishing. https://doi.org/10.1007/978-3-030-23400-3 12.

Annan, Francis and Wolfram Schlenker. 2015. "Federal Crop Insurance and the Disincentive to Adapt to Extreme Heat." American Economic Review: Papers \& Proceedings 105 (5): $262-66$. https://doi.org/10.1257/aer.p20151031. recommendations improve farm resilience to climate change by promoting soil health and crop diversification while reducing GHG emissions.

Changes may be met with resistance by individuals and organizations unconvinced of the value of crop diversification or the need to adapt to climate change. A successful transition demands creativity and collaboration. This multifaceted solution is more likely to shift deeply-ingrained practices, however, by creating new opportunities and fewer restrictions on grower decision-making. Furthermore, while the proposed investment in research and market development requires long-term commitments, rates of return can often reach $12-40$ to 1 (Malla and Brewin 2019). In combination, these improvements will reduce taxpayer burden to provide farm revenue protection in the face of increasing extreme weather events by improving agricultural resilience.

\section{Policy recommendation}

We propose the synergistic combination of changes to FCIP as the most sustainable long-term solution. The USDA can evolve the FCIP to support climate-resilient agriculture by (1) eliminating county-level fallow requirements, (2) funding research and market development for regionallyadapted legumes, and (3) phasing out single-crop, yield-based coverage while incentivizing whole farm insurance. As the rising costs and risks of extreme weather threaten agricultural sustainability, the USDA must act quickly to adjust its far-reaching FCIP program to support practices that reduce fossil energy use and promote soil health and climate resiliency through nature-based solutions.

Beckie, Hugh J., Stuart J. Smyth, Micheal D.K. Owen, and Savannah Gleim. 2019. "Rewarding Best Pest Management Practices via Reduced Crop Insurance Premiums." International Journal of Agronomy 2019. https://doi.org/10.1155/2019/9390501.

Bossio, D.A., S.C. Cook-Patton, P.W. Ellis, J. Fargione, J. Sanderman, P. Smith, S. Wood, et al. 2020. "The Role of Soil Carbon in Natural Climate Solutions." Nature Sustainability $\quad 3 \quad$ (5): 391-98. https://doi.org/10.1038/s41893-020-0491-z.

Bowles, Timothy M., Maria Mooshammer, Yvonne Socolar, Francisco Calderón, Michel A. Cavigelli, Steve W. Culman, William Deen, et al. 2020. "Long-Term Evidence Shows That Crop-Rotation Diversification Increases Agricultural Resilience to Adverse Growing Conditions in North America." One Earth 2 (3): 284-93. https://doi.org/10.1016/i.oneear.2020.02.007. 
Brewin, Derek G., and Stavroula Malla. 2012. "The Consequences of Biotechnology: A Broad View of the Changes in the Canadian Canola Sector, 1969 to 2012." AgBioForum $15 \quad$ (3): 257-75. http://hdl.handle.net/10355/35117.

Bryant, Lara, and Claire O'Connor. 2017. "Covering Crops: How Federal Crop Insurance Program Reforms Can Reduce Costs, Empower Farmers, and Protect Natural Resources."

https://www.nrdc.org/sites/default/files/federalcrop-insurance-program-reforms-ip.pdf.

Cernay, Charles, Tamara Ben-Ari, Elise Pelzer, Jean Marc Meynard, and David Makowski. 2015. "Estimating Variability in Grain Legume Yields across Europe and the Americas." Scientific Reports 5 (1): 1-11. https://doi.org/10.1038/srep11171.

Chenu, Claire, Denis A. Angers, Pierre Barré, Delphine Derrien, Dominique Arrouays, and Jérôme Balesdent. 2019. "Increasing Organic Stocks in Agricultural Soils: Knowledge Gaps and Potential Innovations." Soil and Tillage Research 188 (May): 41-52. https://doi.org/10.1016/j.still.2018.04.011.

Claassen, Roger, Christian Langpap, and Junjie Wu. 2017. "Impacts of Federal Crop Insurance on Land Use and Environmental Quality." American Journal of Agricultural Economics 99 (3): 592-613. https://doi.org/10.1093/ajae/aaw075.

Coe, Michael T., Katherine M. Evans, Ksenija Gasic, and Dorrie Main. 2020. "Plant Breeding Capacity in U.S. Public Institutions." Crop Science 60 (5): 2373-85. https://doi.org/10.1002/csc2.20227.

Crews, Timothy E., and M.B. Peoples. 2004. "Legume versus Fertilizer Sources of Nitrogen: Ecological Tradeoffs and Human Needs." Agriculture, Ecosystems \& Environment $102 \quad$ (3): 279-97. https://doi.org/10.1016/J.AGEE.2003.09.018.

Crews, Timothy E., Wim Carton, and Lennart Olsson. 2018. "Is the Future of Agriculture Perennial? Imperatives and Opportunities to Reinvent Agriculture by Shifting from Annual Monocultures to Perennial Polycultures." Global Sustainability 1 (November): e11. https://doi.org/10.1017/sus.2018.11.

Drinkwater, L. E., P. Wagoner, and M. Sarrantonio. 1998. "Legume-Based Cropping Systems Have Reduced Carbon and Nitrogen Losses." Nature 396 (6708): 26265. https://doi.org/10.1038/24376.

Hamilton, Shane. 2020. "Crop Insurance and the New Deal Roots of Agricultural Financialization in the United States." Enterprise and Society 21 (3): 648-80. https://doi.org/10.1017/eso.2019.43.

Hatfield, J., G. Takle, R. Grotjahn, P. Holden, R.C. Izaurralde, T. Mader, E. Marshall, and J.M. Melillo. 2014. "Ch. 6: Agriculture." In Climate Change Impacts in the United States: The Third National Climate Assessment, 150-74. https://doi.org/10.7930/J02Z13FR.
Hunter, Mitchell C., Richard G. Smith, Meagan E. Schipanski, Lesley W. Atwood, and David A. Mortensen. 2017. "Agriculture in 2050: Recalibrating Targets for Sustainable Intensification." BioScience 67 (4): 386-91. https://doi.org/10.1093/biosci/bix010.

IPCC. 2019. "IPCC Special Report on Climate Change and Land: Chapter 4: Land Degradation." https://www.ipcc.ch/report/srccl/.

Jacob, Cristián, Basilio Carrasco, and Andrés R. Schwember. 2016. "Advances in Breeding and Biotechnology of Legume Crops." Plant Cell, Tissue and Organ Culture. Springer Netherlands. https://doi.org/10.1007/s11240-016-1106-2.

Jensen, Erik Steen, and Henrik Hauggaard-Nielsen. 2003. "How Can Increased Use of Biological $\mathrm{N}_{2}$ Fixation in Agriculture Benefit the Environment?" Plant and Soil $252 \quad$ (1): 177-86. https://doi.org/10.1023/A:1024189029226.

Jensen, Erik Steen, Mark B. Peoples, Robert M. Boddey, Peter M. Gresshoff, Hauggaard Nielsen Henrik, Bruno J.R. Alves, and Malcolm J. Morrison. 2012. Legumes for Mitigation of Climate Change and the Provision of Feedstock for Biofuels and Biorefineries. A Review. Agronomy for Sustainable Development. Vol. 32. https://doi.org/10.1007/s13593-011-0056-7.

Kane, Daniel A., Mark A. Bradford, Emma Fuller, Emily E. Oldfield, and Stephen A. Wood. 2021. "Soil Organic Matter Protects US Maize Yields and Lowers Crop Insurance Payouts under Drought." Environmental Research Letters 16, no. 4: 044018. https://doi.org/10.1088/1748-9326/abe492.

Kern, J.S., and M.G. Johnson. 1993. "Conservation Tillage Impacts on National Soil and Atmospheric Carbon Levels." Soil Science Society of America Journal 57 (1): 200-210.

https://doi.org/10.2136/sssaj1993.03615995005700 010036x.

Knowler, Duncan, and Ben Bradshaw. 2007. "Farmers' Adoption of Conservation Agriculture: A Review and Synthesis of Recent Research." Food Policy 32 (1): 2548. https://doi.org/10.1016/i.foodpol.2006.01.003.

Lal, Rattan. 2018. “Digging Deeper: A Holistic Perspective of Factors Affecting Soil Organic Carbon Sequestration in Agroecosystems." Global Change Biology 24 (8): 3285-3301. https://doi.org/10.1111/gcb.14054.

Li, Long, Jianhao Sun, Fusuo Zhang, Xiaolin Li, Sicun Yang, and Zdenko Rengel. 2001. "Wheat/Maize or Wheat/Soybean Strip Intercropping: I. Yield Advantage and Interspecific Interactions on Nutrients." Field Crops $\begin{array}{llll}\text { Research } & 71 & \text { (2): }\end{array}$ https://doi.org/10.1016/S0378-4290(01)00156-3.

Li, Long, David Tilman, Hans Lambers, and Fu-Suo Zhang. 2014. "Plant Diversity and Overyielding: Insights from Belowground Facilitation of Intercropping in Agriculture." New Phytologist 203 (1): 63-69. https://doi.org/10.1111/nph.12778. 
Lobell, D.B., and S. M. Gourdji. 2012. "The Influence of Climate Change on Global Crop Productivity." Plant $\begin{array}{llll}\text { Physiology } & 160 & \text { (4): } 1686-97 .\end{array}$ https://doi.org/10.1104/pp.112.208298.

Lovett, Jon. 1999. "Linking Social and Ecological Systems. Management Practices and Social Mechanisms for Building Resilience." Environment and Development Economics 4 (2): 237-42. https://doi.org/10.1017/S1355770X99220165.

Maaz, Tai, J.D. Wulfhorst, Vicki McCracken, John Kirkegaard, David R. Huggins, Ildiko Roth, Harsimran Kaur, and William Pan. 2018. "Economic, Policy, and Social Trends and Challenges of Introducing Oilseed and Pulse Crops into Dryland Wheat Cropping Systems." Agriculture, Ecosystems \& Environment 253 (February): 177-94. https://doi.org/10.1016/J.AGEE.2017.03.018.

Meynard, J.M., A. Messéan, A. Charlier, F. Charrier, M. Farès, M. le Bail, M.B. Magrini, and I. Savini. 2013. "Crop Diversification: Obstacles and Levers." Paris. https://www6.paris.inrae.fr/depe/content/download 3817/36308/version/1/file/Etude+DiversificationSynth\%C3\%A8se-def+EN.pdf.

Mulik, Kranti. 2017. "Rotating Crops, Turning Profits." Washington

D.C. https://ucsusa.org/resources/rotating-crops-turningprofits.

Nielsen, David C., Drew J. Lyon, and Juan J. Miceli-Garcia. 2017. "Replacing Fallow with Forage Triticale in a Dryland Wheat-Corn-Fallow Rotation May Increase Profitability." Field Crops Research 203 (March): 22737. https://doi.org/10.1016/i.fcr.2016.12.005.

Nielsen, David C., and Merle F. Vigil. 2010. "Precipitation Storage Efficiency during Fallow in Wheat-Fallow Systems." Agronomy Journal 102 (2): 537-43. https://doi.org/10.2134/agronj2009.0348.

Oldfield, Emily E., Mark A. Bradford, and Stephen A. Wood. 2019. "Global Meta-Analysis of the Relationship between Soil Organic Matter and Crop Yields." Soil 5 (1): 15-32. https://doi.org/10.5194/soil-5-15-2019.

Peoples, M. B., J. Brockwell, D. F. Herridge, I.J. Rochester, B. J.R. Alves, S. Urquiaga, R.M. Boddey, et al. 2009. "The Contributions of Nitrogen-Fixing Crop Legumes to the Productivity of Agricultural Systems." Symbiosis, 48:1$17 . \quad$ Balaban Publishers. https://doi.org/10.1007/BF03179980.

Petersen-Rockney, Margiana, Patrick Baur, Aidee Guzman, S. Franz Bender, Adam Calo, Federico Castillo, Kathryn De Master, et al. 2021. "Narrow and Brittle or Broad and Nimble? Comparing Adaptive Capacity in Simplifying and Diversifying Farming Systems." Frontiers in Sustainable Food Systems 5: 564900. https://doi.org/10.3389/fsufs.2021.564900.

Peterson, G.A., D.G. Westfall, M.E. Schipanski, and S.J. Fonte. 2020. "Soil and Crop Management Systems That Ameliorate Damage Caused by Decades of Dryland Agroecosystem Mismanagement." Agronomy Journal, May, 1-12. https://doi.org/10.1002/agj2.20257.
Plant Breeding Working Group, USDA. 2015. "USDA Roadmap for Plant Breeding." Washington DC. https://www.usda.gov/sites/default/files/documents Lusda-roadmap-plant-breeding.pdf.

Ray, Deepak K., James S. Gerber, Graham K. Macdonald, and Paul C. West. 2015. "Climate Variation Explains a Third of Global Crop Yield Variability." Nature $\begin{array}{llll}\text { Communications } & 6 & \text { (1): } & 1-9 .\end{array}$ https://doi.org/10.1038/ncomms6989.

Risk Management Agency (RMA). 2016. "Good Farming Practice Determination Standards Handbook." Washington D.C. https://www.rma.usda.gov/Lmedia/RMA/Handbooks/Program-Administration-14000/Good-Farming-Practice/2017-14060-1HGood-Farming-Practice-Determination-Standards.ashx. Robertson, Andy D., Yao Zhang, Lucretia A. Sherrod, Steven T. Rosenzweig, Liwang Ma, Lajpat Ahuja, and Meagan E. Schipanski. 2018. "Climate Change Impacts on Yields and Soil Carbon in Row Crop Dryland Agriculture." Journal of Environmental Quality 47 (4): 684-94. https://doi.org/10.2134/jeq2017.08.0309.

Rosenzweig, Steven T., Michael S. Carolan, and Meagan E. Schipanski. 2019. "A Dryland Cropping Revolution? Linking an Emerging Soil Health Paradigm with Shifting Social Fields among Wheat Growers of the High Plains." Rural Sociology $85 \quad$ (2): $\quad 545-74$. https://doi.org/10.1111/ruso.12304.

Rosenzweig, Steven T., Steven J. Fonte, and Meagan E. Schipanski. 2018. "Intensifying Rotations Increases Soil Carbon, Fungi, and Aggregation in Semi-Arid Agroecosystems." Agriculture, Ecosystems \& Environment 258: 14-22. https://doi.org/10.1016/i.agee.2018.01.016.

Rosenzweig, Steven T., and Meagan E. Schipanski. 2019. "Landscape-Scale Cropping Changes in the High Plains: Economic and Environmental Implications." Environmental Research Letters 14 (12): 124088. https://doi.org/10.1088/1748-9326/ab5e8b.

Rubiales, Diego, Sara Fondevilla, Weidong Chen, Laurent Gentzbittel, Thomas J.V. Higgins, María A. Castillejo, Karam B. Singh, and Nicolas Rispail. 2015. "Achievements and Challenges in Legume Breeding for Pest and Disease Resistance." Critical Reviews in Plant Sciences $\quad 34 \quad$ (1-3): 195-236. https://doi.org/10.1080/07352689.2014.898445.

Sanderman, Jonathan, Tomislav Hengl, and Gregory J. Fiske. 2017. "Soil Carbon Debt of 12,000 Years of Human Land Use." Proceedings of the National Academy of Sciences of the United States of America 114 (36): 9575-80. https://doi.org/10.1073/pnas.1706103114.

Stagnari, Fabio, Albino Maggio, Angelica Galieni, and Michele Pisante. 2017. "Multiple Benefits of Legumes for Agriculture Sustainability: An Overview." Chemical and Biological Technologies in Agriculture 4 (2). https://doi.org/10.1186/s40538-016-0085-1. 
Stepanovic, Strahinja, Ben Dutton, Lucas Haag, Brian Talamantes, and Ron Meyer. 2016. "Replacing Summer Fallow with Grain-Type Field Peas: New Markets, New Opportunities." University of Nebraska Cropwatch, July 14, 2016. https://cropwatch.unl.edu/2016/replacingsummer-fallow-grain-type-field-peas-new-marketsopportunities.

Tack, Jesse, Keith Coble, and Barry Barnett. 2018. "Warming Temperatures Will Likely Induce Higher Premium Rates and Government Outlays for the U.S. Crop Insurance Program." Agricultural Economics 49 (5): 635-47. https://doi.org/10.1111/agec.12448.

Tilman, David, Kenneth G. Cassman, Pamela A. Matson, Rosamond Naylor, and Stephen Polasky. 2002. "Agricultural Sustainability and Intensive Production Practices." Nature. https://doi.org/10.1038/nature01014.

U.S. Government Accountability Office. 2015. "Crop Insurance: In Areas with Higher Crop Production Risks, Costs Are Greater, and Premiums May Not Cover Expected Losses." Federal Crop Insurance: Background and Costs of Insuring Higher Production Risks. https://www.gao.gov/products/gao-15-215.
Wahbi, Sanâa, Tasnime Maghraoui, Mohamed Hafidi, Hervé Sanguin, Khalid Oufdou, Yves Prin, Robin Duponnois, and Antoine Galiana. 2016. "Enhanced Transfer of Biologically Fixed $N$ from Faba Bean to Intercropped Wheat through Mycorrhizal Symbiosis." Applied Soil Ecology $107 \quad$ (November): $91-98$. https://doi.org/10.1016/i.apsoil.2016.05.008.

Wienhold, Brian J., Merle F. Vigil, John R. Hendrickson, and Justin D. Derner. 2018. "Vulnerability of Crops and Croplands in the US Northern Plains to Predicted Climate Change." Climatic Change 146 (1-2): 219-30. https://doi.org/10.1007/s10584-017-1989-x.

Zander, Peter, T.S. Amjath-Babu, Sara Preissel, Moritz Reckling, Andrea Bues, Nicole Schläfke, Tom Kuhlman, et al. 2016. "Grain Legume Decline and Potential Recovery in European Agriculture: A Review." Agronomy for Sustainable Development 36 (26). https://doi.org/10.1007/s13593-016-0365-y.

Laura K. van der Pol is a National Science Foundation (NSF) Fellow pursuing a PhD in Soil Ecology. She studies soil organic matter dynamics in agroecosystems with a focus on pathways to sustainable food systems. Laura strives to enhance scientific literacy and engage in science-informed policy and communication.

Clara Tibbetts is a fifth-year $\mathrm{PhD}$ candidate in Chemistry with a focus in the use of ultrafast nonlinear optics to study energy storage and renewable energy systems at Colorado State University (CSU). In addition to scientific research, Clara is interested in science policy and communication, and currently leads the Science in Action organization at CSU.

Danielle E. Lin Hunter is a fourth-year PhD candidate in Ecology with a Human Environment Interactions emphasis in the Graduate Degree Program in Ecology at CSU. She is interested in social-ecological systems and public engagement in science.

\section{Acknowledgements}

The authors would like to thank Aleta Weller, Laura Shaver, and Dr. Diana Wall at the School of Global Environmental Sustainability at CSU for bringing us together through the Sustainability Leadership Fellowship. We would also like to thank members of the Agroecology Lab for their helpful comments, Dr. Stephen Rosenzweig and Dr. Meagan Schipanski, whose research inspired this memo, as well as the countless farmers whose livelihoods and research participation made possible our current understanding of paths towards agricultural resilience. Laura K. van der Pol is supported by the NSF Graduate Research Fellowship Program.

\section{Disclaimer}

The authors disclose that they have no conflicts of interest to report. 